\title{
Editorial
}

\section{Entomopathogenic Bacterial Toxins as Biological Control Agents}

Green tendencies are invading all aspects of our life during the last decades. Use of environment friendly and cost effective alternatives to industrial chemicals such as bio-fuels, bio-fertilizers and bio-pesticides result in improved health and safety standards, enhanced crop output, and lower levels of pollution. The ever increasing demand of agricultural produce has given new impetus to research in the field and has resulted in great benefits for farmers and consumers alike. Toxins of entomopathogenic bacteria have become the leading bio-pesticides commercially used to control populations of insect pests as well as vectors transmitting severe human diseases.

This supplementary issue includes recent data covering major aspects of entomo-pathogenic bacteria such as molecular and genetic methods to improve toxicity, modes of toxin action and synergy, evolution of insect resistance and persistence of the toxins in the environment. Understanding the action mechanisms of these bacterial toxins and the modes by which insects acquire resistance to them will provide the foundations for taking measures to counter resistance, for durable use of formulations, and to construct transgenic crops to replace synthetic insecticides.

The first two chapters describe the basic biological and molecular parameters of the insecticidal polypeptides from several bacterial species, being rich sources of such toxins, and examples of how to obtain artificially improved products by manipulating their genomes. Molecular mechanisms of membrane perforation responsible for toxicity are elaborated in the third chapter. The forth chapter discusses cross-resistance among the toxins, ways to assess risks and to monitor resistance acquisition by the targets, and strategies to minimize or prevent it, and the fifth suggests examples of specific ways to circumvent resistance by synergistic interactions. The last chapter deals with environmental hazards consequent to extensive use of this means to combat insect pests due to toxin persistence in nature.

The special issue is intended to serve as a long-standing source of basic knowledge covering most aspects of the subject matter. The cooperation of all contributors and editorial office is gratefully acknowledged.

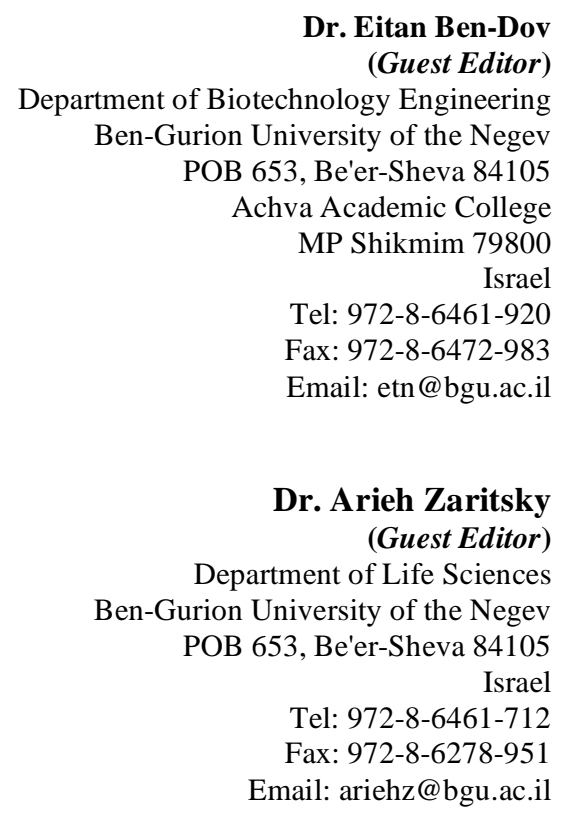

(c) Ben-Dov and Zaritsky; Licensee Bentham Open.

This is an open access article licensed under the terms of the Creative Commons Attribution Non-Commercial License (http: //creativecommons.org/licenses/by$\mathrm{nc} / 3.0 /$ ) which permits unrestricted, non-commercial use, distribution and reproduction in any medium, provided the work is properly cited. 